ISSN :

Print - 2277-078X

Online - $2315-747 \mathrm{X}$

(c) UNAAB 2019

Journal of

H umanities, Social

Sciences and Creative

Arts

\title{
THE ROLE OF THE NIGERIAN SECURITY AND CIVIL DEFENCE CORPS IN THE 2019 ELECTIONS: A STUDY OF FOUR LOCAL GOVERNMENT AREAS IN OGUN STATE
}

\author{
${ }^{*}$ 1S. ABDUSSOBUR AND 2D. A. YAGBOYAJU \\ 1Institute for Peace and Strategic Studies, University of Ibadan \\ 2D epartment of Political Science, University of Ibadan \\ *Corresponding Author: reachabdel@yahoo.com Tel: +2348038098700
}

\begin{abstract}
The 2019 general elections are the sixth set of elections in Nigeria's twenty years of uninterrupted democratic experiment. Studies have concentrated on the roles of the Nigerian Army and Police in the security aspects of elections in the country with little attention paid to the impact of the Nigerian Security and Civil Defence Corps (NSCDC) in electoral security. This study investigates the significance of NSCDC in electoral security. Selected study area consists of the four Local Government Areas (LGAs) which make up Abeokuta, the capital city of Ogun State. This is a strategic state in view of its international boundaries with Republic of Benin, and the history of cross border criminal acts. Data are drawn from primary and secondary sources, while the interpretative method of analysis is adopted. The study established that the Corps was very suited for election duties due to its more civil disposition and a more positive integrity and credibility perception. The study therefore recommends that the NSCDC should be legally empowered to play more active roles in election security and strengthened in terms of manpower and equipment in order to enhance its roles during elections.
\end{abstract}

Keywords: Cross- border criminal acts, Violence, Electoral security, NSCDC, Ogun state, Nigeria

\section{INTRODUCTION}

Nigeria's elections continue to be trailed by extensive violence even after twenty years of uninterrupted civilian rule in its third wave of democratic experience. While democracy is a pre-condition for good governance, its credibility could be undermined by lack of integrity in the electoral process (Keane, 2004). The first post- transition election of 2003 witnessed the deaths of over one hundred people with twice that number injured (Bekoe, 2011). Over three hundred deaths were recorded in violence linked to the 2007 general elections, while the 2011 general elections, despite its acclaim of being well managed, recorded the highest incidences of electoral violence that claimed over eight hundred lives and displaced over sixty five thousand people (Human Rights Watch, 2011). In the 2015 general elections, despite the history recorded with the concession of President Goodluck Jonathan to President Muhammadu Buhari, no less than one hundred deaths were recorded during and after the elections (International Crisis Group, 2018). The European Union Report on the 2019 general elections observed that the elections, which were marred by violence 
and intimidation, recorded over one hundred and fifty deaths. These deaths included that of a member of the Federal House of Representatives. One hundred and twenty eight people were arrested for election related offences which included ballot box snatching, vote trading, impersonation and the possession of arms and even bombs (Anna \& Muhumuza, 2019). The EU report further highlighted the intimidation of INEC officials in twenty states and the attacks on INEC offices, abductions and sexual assault on INEC officials, while the security agencies were ineffective at protecting citizens' right to vote.

While the responsibility of law enforcement lies largely on the shoulders of the Nigeria Police, some other agencies such as the Nigerian Security and Civil Defence Corps (NSCDC) have also been saddled with the responsibility of supporting the Police in this onerous task.

Established in 1967 but given full legal status in 2007, the NSCD C is a paramilitary institution commissioned to provide measures against threat and any form of attack or disaster against the nation and its citizens. The Corps is statutorily empowered by Act No 2 of 2003 and amended by Act 6 of 2007 with the primary function of protecting lives and property in conjunction with the Nigeria Police. The corps has a mandate to assist in maintaining peace and order, protecting and rescuing the civil population during periods of emergency and maintaining surveillance over infrastructures, sites and project for the Federal, State and Local G overnments, and have power to make arrest of any person reasonably suspected to have committed a criminal activity aimed at frustrating the government.
Prior to, and after the February 2019 elections in Nigeria, there were intense debates on the roles of security and law enforcement agencies in elections. Their roles in elections became even more contentious after the 2018 governorship elections in Ekiti and O sun States, where there were accusations and counter accusations over the use of security agencies to intimidate voters, rig elections and falsify results (Iyare, 2018; O latunji, 2018; Azimazi and Terhemba, 2018). While the basic responsibility of security agencies are to maintain law and order in society, their roles become more crucial as specified by statutes, to ensure and provide an enabling environment for elections. The credibility and outcome of elections depend largely on the Independent National Electoral Commission (INEC), but the political class and the security agencies no doubt play a major role. To this extent, the Nigerian Security and Civil Defence Corps becomes a critical stakeholder to the success of elections in Nigeria.

\section{Statement of the Problem}

One of the major challenges of the electoral process in Nigeria is the issue of electoral malpractice and violence- before, during and after elections. The character of Nigerian politics promotes a culture of desperation because of the high stakes involved owing to the enormous spoils that the elected office brings. To this end, Nigeria's elections are often characterized by "life and death" affairs and its politics described as "zero sum". This is because of the high stakes battle for the huge rewards of office which include the control of power and economy by members of the political class at a heavy human, physical and economic cost to the nation (Albert, 2007). While the conduct of credible elections rests on the capacity of the electoral agency, voters and politicians, the security 
THE ROLE OF THE NSCDC IN THE 2019 ELECTIO NS...

agencies play major roles in striking a balance of law and order in the process. The basic responsibility of law enforcement agencies which are to ensure the security of lives and properties become more in demand during elections. This is in spite of the perceived inefficiencies, allegations of bias and compromise and supposed intimidation and militarization of the process by the security agencies.

Works abound on the roles of the electoral agency, political class and voters in ensuring credible election (Norman, 2010: Olurode, 2013; Carlos, 2014; Sakhawat, 2017). Although the stakeholders in ensuring credible elections include security agencies, less attention has been paid to their roles and even when this is done, the focus has been more on the Nigerian Army and the Police. The Nigeria Police, which though has the primary responsibility of ensuring security, safety and law enforcement during elections, does not perform the function alone without the necessary backup and support of other agencies including the NSCD C.

This research investigates the role of the NSCD C, as a law enforcement agency, in ensuring free, fair and credible elections in Nigeria. It examines the statutory mandate of the agency, its functionality, effectiveness and efficiency in the electoral process with a view to determining the justification of the heavy financial investments and confidence by the government and other stakeholders in the NSCDC in participating in election duties. Four local government areas are selected for the study. These are namely: Abeokuta North, Abeokuta South, Odeda and Obafemi Owode local governments in Ogun State. Abeokuta, the capital city of Ogun State, is covered in different ways by the four selected LGAs. This choice of Abeokuta became necessary based on the early warning signs identified during the violent pre-election activities culminating in an attack on the incumbent President Muhammadu Buhari and the APC leadership during the party's campaign rally in Abeokuta (Bosun, 2019).

\section{Research Q uestions and 0 bjectives}

This study seeks to answer three questions:

(1) What are the roles of the NSCD C in preelection, actual election and post-election activities?

(2) How does the NSCDC give support to the lead security agency for elections (the Nigeria Police) and the Independent National Electoral Commission?

(3) How can the activities of the NSCDC be enhanced for the purposes of future elections in Nigeria?

The following are the objectives of the study:

(1) To assess the roles of the NSCDC in ensuring credible elections in Nigeria.

(2) To examine the relationship between the NSCDC and other stakeholders in ensuring credible elections in Nigeria

(3) To suggest means by which the roles and activities of the NSCDC can be enhanced for election security.

\section{Theoretical Framework}

This study approaches the research questions and objectives using the Structural Functional Theory. The Structural Functional Theory presupposes that the society is a single but interconnected system with each element performing a specific function. A system is comprehensive in the sense that it includes all the interactions- inputs and outputs (Almond, 2001). The theory emphasizes the formal ordering of parts and their functional interrelationship in contributing to the needs of the entire system. Thus, the function of 
any institution such as the NSCDC is the part it plays in the maintenance of the larger structural whole, which can be seen as the entire security architecture in the electoral process. The Structural Functional theory as an analytical tool provides a comprehensive insight into the roles of an institution within a larger organization. Carlos (2014) maintains that the responsibility for credible elections which lies largely with the electoral body, is not a lonesome responsibility and requires the involvement of other stakeholders- political parties, security agencies, civil society, the media and even the voters, though this responsibility lies in varying degrees. G oing further, Norman (2010) argues that the resilience of election stakeholders is vested in the ability to perceive elections systematically and sustainably and knowledge of elections is vital in harnessing the perception and performance of these institutions.

The theory is however criticized despite its utilitarian function because of its inability to account for social change and its attempt to only describe the effects of a social institution or phenomenon without being able to identify its causes. D espite its criticism however, the theory is still relevant because it gives deeper insights into the roles, structures and functions of an organization within the system, in this case the NSCD C within the entire electoral security system and how the organization plays roles in the maintenance of electoral order which could assist all stakeholders in taking informed decisions with regards to the roles of the NSCD C in election security.

\section{LITERATURE REVIEW}

The roles of elections as mechanisms through which governments are held accountable and peaceful transfers of power are made with the consent of the majority are captured in various works (Eya, 2003; Thomassen, 2014; Egobueze and Ojirika, 2017). Nwolise (2007) described elections as a process of electing the officers or representatives of an organization or group by the vote of its qualified members. In any credible democracy, elections constitute the soul of the democratic process (Joseph, 2011). Describing the benefit of elections within the context of popular competence, Rosseau (1950) stated that the general will is always right and tends to the public advantage. This was corroborated by Pomper (1967) who contended that legitimacy is the empirical result of popular elections. D emocratic governance is conducted mostly through representatives and therefore, elections are held periodically to elect representatives for the purpose of governance. The integrity of an election is based on the democratic principle of universal suffrage, political equity as reflected in international standards, professional, impartial and transparent administration of the electoral cycle from pre-electoral period, the polling day and its aftermath (Sakhawat, 2012).

Nigeria's elections are blighted by violence and anomalies because of the high stakes battle for huge rewards of office and control of power between individuals and ethnic and religious identity groups (Kimenyi and Mbaku, 2011; Campbell, 2019). The challenge of peaceful elections are further exacerbated by various ethno- religious tensions in the country, massive poverty and unemployment which has led to increased numbers of thugs and criminal groups. There were about nine hundred and fifteen cases of election violence resulting in almost about four thousand deaths between June 2006 and May 2014 (International Crisis G roup, 2018). 
THE ROLE OF THE NSCDC IN THE 2019 ELECTIO NS...

The role of security agencies, especially the Army, in election duties has been a source of serious contention. Some opinions stem their support for military duties from the 1999 Constitution "to restore order if needed and in cases of insurrection" and on the general insecurity in the country which has propensity to expose politicians, their agents and the electorate to grave danger during elections (Otaiku, 2018). Another school of thought (Abutudu and Obadheko; Olurode, 2013; Ume, Chibuike and $\mathrm{Onu}, 2016)$ contend that military involvements in elections amount to an aberration. For example, Olurode (2013) noted that security agents conceive of their roles as securing the lives and properties of the big men in power rather than policing the state. Several contested legal rulings (FHC/ S/ CS/ 29/2014) have also restrained the President and Commander- in- Chief from engaging the services of the Nigerian Armed Forces in security supervision of elections in any manner whatsoever in any part of Nigeria without an act of the $\mathrm{Na}$ tional Assembly (Abutudu and Obadheko, 2016). This legal position is supported by the opinion of the researchers that the $\mathrm{Ni}$ gerian Army as at today, places more emphasis on regime protection than on protection of the state and as such should not be given a place in the electoral process of the country.

The onus of security during elections should lie largely on the Police, with the support of the NSCD C and other agencies such as Immigration Services, Custom Services and Federal Road Safety Corps (FRSC). O ne perspective holds that credible elections are possible in Nigeria only if security personnel including the military are massively deployed (Olurode and Hammange, 2013). This perception is fuelled by the seeming indispensability of security agencies in previous elections, which have been characterized by thuggery, violence and electoral malpractices and assumes that electoral malpractices are inseparable from elections in Nigeria and only a militarization of elections can stem the tide of electoral malpractices. It is perhaps against this background that the presidential order to security agents ahead of the 2019 elections to kill any person who attempted to snatch ballot boxes is situated (Punch, Feb. 20, 2019; Vanguard, Feb.19, 2019). This has however been criticized by Onyema (2019) who argues that such presidential order portends great danger for the electoral process as it has potential to embolden trigger happy security agents to take laws into their hands, thereby leading not only to human rights breaches but killing of innocent Nigerians. IsraelAyide (2019) therefore insists that as much as possible, arms bearing law enforcement agents should sparingly be involved in elections, because of the propensity for promoting voter apathy, tensions and other negative implications.

The history of the involvement of the $\mathrm{Ni}$ gerian Police in elections and democratic governance can be traced to the country's colonial Native Authority days where they were used to carry out the wishes of the colonial government in oppressing and subjugating the populace (Otwin, 1985). Balogun (2013), in assessing the role of the Nigerian Police Force in the first republic, noted that the police were not insulated from the control of the ruling party and as such, compromised its roles in the 1962 crisis by being used by the ruling NPC and NCNC as an instrument to deal with the AG. The compromise of the Nigerian Police also manifested as Olasupo (2003) noted that "the Mobile Police Operations (MOPOL), other- 
wise known as "Kill and Go", was used to terrorize citizens in the second republic such that electoral frauds were perpetrated easily in some areas where citizens were so much intimidated that they could not go out and exercise their legitimate and constitutional rights to vote for aspirants of their choice". These opinions about the Nigerian Police have entered into the third and fourth republics without any change in the perception of the populace and scholars.

The roles of security agencies in election security are captured by Mediayanose (2018) to include providing security for candidates during rallies, congresses, conventions, election campaigns; safeguarding the lives and properties of citizens during the electoral process; ensuring and preserving a free, fair, safe and lawful atmosphere for campaigning by all parties and candidates without discrimination; maintaining peaceful conditions law and order around the polling and collation centers, providing security for electoral officials at the voting and counting centers; ensuring the security of election materials at the voting center and during transportation; ensuring the security of all election materials, personnel and citizens during registration of votes, updates, revision and any other electoral event. This is corroborated by Igini (2013), who sees election security as the key to the integrity of electorates, electoral personnel, electoral materials, contestants, election monitors, and other stakeholders who participate in the electoral process. He broadly categorizes election security as firstly the security of participants and secondly, the security of election materials, which include sensitive and non- sensitive materials.

D espite the great responsibilities of the Police during elections, there are challenges of inadequate funding, poor logistic planning, ineffective interagency communication and a capacity deficit including personnel shortfalls. The Nigeria Police has 370,000 personnel to cover 119, 973 polling units (Arowolo, 2019), thereby making the manpower strength grossly inadequate. Dooba (2019) estimated that the 2019 elections witnessed the registration of 84 million voters, making it the largest database of citizens in Africa and one of the largest in the world. Comparing the registered voters with the number of police officers shows the enormity of the challenge before the Police in election security.

As observed by D ooba (2019), whereas the presence of the Police should ordinarily reassure voters, this is not the case, because the average citizen suspects the motives of the police in view of past experiences. Oni, Chidozie and Agbude (2013) in analyzing the mode of operation of the Nigerian Police in handling election responsibilities maintain that it is how the Nigerian Police performs their roles of electoral security that needs attention and not the issue of whether these roles are being executed and concluded that any electoral reforms that excludes the reformation of the security agencies is an incomplete exercise. This viewpoint is shared by INEC Chairman, Professor Mahmud Yakub, in an assertion that the Nigeria Police remains "the lead agency for election security (D aily Trust, January 19, 2019). He concludes however, that there is a need for a "new security architecture" which is consistent with the provisions of Section 29(3) of the 2010 Electoral Act. It is with these observations on the need to review the existing security architecture, that a research into the role of not only the lead agency, but also supporting agencies like the NSCDC becomes pertinent. 
THE ROLE OF THE NSCDC IN THE 2019 ELECTIO NS...

\section{METHODOLOGY}

The study area is Abeokuta North, Abeokuta South, Odeda and Obafemi O wode which make up the four local governments situated in the $O$ gun State capital of Abeokuta. Apart from hosting the seat of the state government, they also host the headquarters of all security and law enforcement agencies in 0 gun state. With a joint population of 787,388 (2006 census), the local governments make up the Ogun Central Senatorial District. Prior to the 2019 elections, Ogun state was predicated as a "complex risk", "highly volatile", environment (United States Institute for Peace Report, 2018). A higher profile race was predicted because the incumbent was no longer in the race, thereby making the election more competitive and open to electoral conflicts which would require greater involvement of security agencies. This prediction came to pass especially in the run- up to the elections when different levels of electoral violence came to play (KayodeAdedeji, 2019; Gyamfi, 2019). The four selected Local Governments, being hosts to the State Capital were the centers of and greatly affected by different forms of electoral conflicts and violence, hence their choice for this research.

The study is based on primary sources using twelve Key Informant Interviews which included an INEC State Resident Electoral Commissioner, the Divisional Officers (Heads) of the NSCDC in the four selected local governments, two Assistant Commandant of Corps who supervised the elections in the four selected Local Governments, a Divisional Police Officer of the Nigeria Police and four Polling O fficers who conducted elections at polling centers each, across the four selected Local Governments. This was after the researcher had undertaken a non- participant observer status in the 2019 elections where the activities of officers of the agency were covertly monitored. Further information was gleaned from twenty respondents purposively sampled, five each from the four local governments, chosen on the basis of having participated and voted in the elections to give their perceptions on the role of the NSCDC in the exercise. The data were analyzed using the content, descriptive and narrative styles.

Secondary data were obtained from scholarly articles and election observer group reports.

\section{Discussion of Findings}

Using the statutory functions and duties of the NSCD C as the pivot, findings made in the study are discussed and analyzed below:

\section{Pre -E lection activities}

It was discovered that prior to the 2019 elections, various agencies, most notably the Independent National Electoral Commission (INEC) and the National Orientation Agency (NOA) in O gun state, organized stakeholders meetings and sensitization trainings for senior personnel of all security agencies, among which included the NSCDC. The senior personnel were sensitized on the general conduct and procedures of the elections and the roles of the security agencies. With the information received from INEC and NOA, the State Headquarters of the agency also organized training reviews which served to appraise their levels of preparedness and agree on lines of action. Based on all the trainings, Heads of Divisions resident in the various Local Government Areas also trained their men, enlightening them on the do's and don'ts of the elections.

The State Resident Electoral Commissioner constituted the Inter-agency Consultative Committee on Election Security (ICCES) 
comprising the State REC, State Administrative Secretary and heads of security agencies including the Police, D SS, Airforce, $\mathrm{Na}$ vy, Customs, Prisons, NDLEA and the NSCDC to plan and coordinate the security of the election. An election situation room was set up with schedule officers assigned by the heads of the various agencies to receive feedbacks from the fields and direct officers and men accordingly. This initiative was done with the purpose of promoting interagency cooperation and collaboration during the election exercise.

The nature of the campaigns and their tendencies to turn violent required the participation of officers and men of the NSCDC who undertook overt and covert monitoring of rallies, town hall meetings, processions and other activities. At such meetings, they monitored the language, actions and reactions of participants and political actors with a view to anticipating and preempting violence. Where these occurred, they sought ways of calming tensions and sometimes invited parties to discuss the development with a view to ensuring that the violent tendencies do not escalate. They also monitored campaign materials of all the parties- billboards, posters and other insignia and prevented the mutilation and destruction of such, and preventing parties from taking laws into their hands.

One significant observation however, was the use of men of the NSCDC as orderlies for politicians otherwise known as VIP's who follow the politicians to whom they were attached to campaign rallies. While during the elections, the orderlies attached to politicians were withdrawn to perform election duties, their use as escorts and orderlies during the campaign period had eroded on the confidence of political actors and electorates and given a perception of partisanship and partiality of officers of the agency in elections. O wing to social relationships already established between the officers of the Corps and the politicians to whom they are attached, some of these officers were said to engage in unwholesome activities which impugn not only on the integrity of the Corps but also on the credibility of the elections.

\section{E lection activity}

Core election activity did not commence on the day of the election but a minimum of three days before, when sensitive and nonsensitive election materials were transported to the various states and local governments. The Electoral Officers informed the security agencies of the estimated time of arrival of the materials and when they arrived, the NSCDC officers along with the Police participated in the inspection of the materials. In the presence of the officers, the materials were further delineated and divided according to the various wards. One major feature of the 2019 elections was that the ballot sheets were not uniform across all states and local governments and serial numbering was followed for wards under local governments.

These measures totally forestalled incidents of ballot stuffing and other malpractices related to bulk transfer of election materials. While the officers did not personally handle the materials, they gave security back up during the movements of the materials from the INEC state office to the Registration Area Centers (RAC), which took place a day preceding the elections. The security officers and polling officers did not leave the Registration Area Centers until the next day (Election D ay), when they escorted materials to various polling units. Their core duties at the polling units were to monitor the activi- 
THE ROLE OF THE NSCDC IN THE 2019 ELECTIO NS...

ties of the Election O fficers and in collaborations with INEC and other security agencies, they ensured voters complied with the electoral laws such as non- usage of phones in the voting cubicle, voters not coming to the polling area with bottles and sharp objects, keeping a three hundred kilometer radius away from the voting center, among others.

Findings however revealed that practical realities of the voting environment determined how officers of the NSCDC addressed emerging challenges during the voting exercise and what obtained in polling units, while the reactions of officers and men differed based on what was on ground. It was discovered that though the incidences of election violence were minimal during the voting, this was replaced by rampant cases of vote trading and while no incidence of arrest was made directly by the agency, back up support was given to the Economic and Financial Crimes Commission in two places where vote trading were intercepted. Although a few skirmishes ensued in the course of the elections, men of the Nigeria Police and the NSCDC were able to contain them and prevent them from escalating.

Observations revealed that one of the major causes of conflicts with tendency to escalate to violence was the inefficiency of most of the Polling $O$ fficers who are members of the National Youth Service Corps (NYSC). Findings revealed that their poor handling of the processes led to conflicts and tensions in the polling units. Probing further, it was discovered that many of the Polling Officers were not well trained on the election duty thereby posing great challenge to the process. In-depth probe revealed that a large number of the people were trained were not mobilized, while those who were engaged were not trained. To however preempt the possibility of violence, even while members of the Corps were without arms, monitoring teams were deployed, patrolling from location to location. There were however serious challenges of non-availability of enough vehicles to move around the beats at the same time. A control room situated at the State Headquarters also monitored developments and gave operational information and orders as situations arose even though there were also challenges of communication gadgets and accessories.

An issue that drew special attention is interagency rivalry or cooperation. Despite the Interagency Consultative Committee on Election Security, there were a few avoidable disagreements between the Police and the other agencies. These disagreements bordered largely on feelings of superiority of the Police to other agencies. Officers of the NSCDC interviewed, complained that officers and men from other agencies tended to look down on officers and men from NSCD C, and assumed a sense of superiority over them. Inspite of this however, there was still a relatively cordial relationship between the agencies during the elections. Though a few frictions ensued among the rank and file, the officers were able to contain the disagreements and nip them in the bud.

Findings revealed that there was however a higher level of confidence in the NSCD C by voter respondents interacted with than in the other agencies, including the Nigeria Police. This was also corroborated by the INEC officials who rated them very high in their conducts and professional disposition to electoral matters. This higher confidence in the NSCDC was discovered to be brought 
about because of the seemingly better relationship they have with the civilian populace and the perception that though they are also an arms bearing agency, their officers and men do not parade arms as much as other agencies, thereby creating terror and psychological threats. The preponderant opinion of respondents was that the Police appeared partisan and their activities appeared to be at the behest and to serve the bidding of the ruling authority. Respondents explained that they were not necessarily assured by the presence of the Police and that the presence of armed men at Polling Units had a disturbing effect on their psyches. As such, they tended to relate better with the NSCDC officers who guided them through the process, counseled against unruly conduct and generally maintained peace without any form of threat or violence.

\section{Post- E lection activity}

Following the elections, the security agencies monitored the movement of the materials to the Collation Center and secured the environment for the collation exercise, announcements and other formalities. To ensure the transparency of the exercise, the officers were also availed copies of the result sheets in the polling units they supervised. They were also deployed to various earlier identified flashpoints to forestall any possible breach of peace arising from the announcement of results. This never occurred as the announcement was met with no negative reactions in the Local Governments.

After the entire exercise, there is a general review or appraisal of the exercise before officers and men are debriefed.

\section{CONCLUSION}

This research investigated the roles of the Nigeria Security and Civil Defence Corps in the 2019 elections and established that the Corps was very suited for election duties due to its more civil disposition, less display of arms in its activities and a more positive integrity and credibility perception. The research contends that while the use of more aggressive security agencies may be necessary in some flash points, the NSCDC given its civil disposition and relations with the citizenry, would be more suited for election duties. Consequently, there is need to restructure the agency and empower it statutorily to have as one of its core mandates, security and law enforcement during elections.

\section{RECOMMEN DATIONS}

1. The NSCDC should be empowered through the enactment of enabling laws and amendment of the Electoral Act to play a more statutory role in election security because of their more civil disposition and the strong confidence of the civilian populace in the agency.

2. Training of Officers and men on election duties should be improved so as to enhance the roles of the agency in the election exercises.

3. Officers and men of the NSCDC should be withdrawn and not assigned as orderlies or security aides. This is because it erodes the confidence of the civilian populace.

4. Polling Officers should be better trained on the election duties. People who have not been trained should not be deployed for election duties.

5. Inter- agency collaboration must be encouraged through education and enlightenment of officers and men of all security agencies.

6. The security manpower resource 
THE ROLE OF THE NSCDC IN THE 2019 ELECTIO NS...

should be increased to cater for the demands on manpower during elections.

7. There is need for a scientific deployment of security personnel during elections beyond random deployments which are sometimes influenced by social and political factors.

8. The NSCD C should be better equipped with operational vehicles and communication gadgets to enhance its productivity during the election process.

\section{REFERENCES}

Albert, I.0., Marco, D., Adetula, V. 2007. Perspectives on the 2003 Elections in Nigeria. (A buja: Stirling- Holden Publishers).

Almond, G. 2001. Modern Political Theory. New Delhi. Vikas Publishing House. PVT Limited.

Anna, C., Muhumuza, R. 2019. Nigeria votes for second day in election marred by deadly violence. TimeMagazine

Angerbrandt, H. 2018. D eadly Elections: Post- Election Violence in Nigeria. TheJar nal of ModamAfrican Studies56(1)

Arowolo, D.E. 2019. Security Agencies and the 2019 elections in Nigeria. KujengaAmai. Social Saiences ResearchCamil.

Azimazi, M.J., Terhemba, D. 2018. O sun Elections: Police throw teargas at Secondus, Saraki during Abuja Protest. GuardanNens paper.

Balogun, A. 2013. An Assessment of the partisan role of the Nigeria Police Force in the 1962 Action Group crisis. Jaumal of His torical Socity of Nigria 22(3)

Bekoe, D. 2012. Nigeria's 2011 Elections:
Best Run, Most Violent. Washington DC. United States Institute of Peace in www.usip.com

Bewaji, W. 2019. President Buhari's directive against ballot box snatchers in order COD ER. Pundh Nenspaper.

Bosun, T. 2019. Violence Breaks out at O gun APC Rally. PunchNenspaper.

Burke, E. 2015. Reflections on Revolutions in France and other writings. New York. Everyman's Library.

Campbell, J. 2019. Tracking Election Violence in Nigeria. Camil forForign Retations in www.foreignaffairs.com

Carlos, V. 2014. The impact of EMBS and other electoral stakeholders on the credibility and acceptance of an electoral process. www.undp.org

Correspondent. 2019. Ballot Box snatchers: I have ordered Army, Police to be ruthlessBuhari. VanguardNenspaper.

Dooba, I. 2019. Helpless Police? The Roles of Security Agents during Elections. Daily Trust Nenspaper.

Egobueze, A., Ojirika C. 2017. Electoral Violence in Nigeria's Fourth Republic: Implications for Political Stability. Jaumal of SaientificResearch13(2)

Eya, N. 2003. Electoral Processes, Electoral Malpractices and Electoral Violence. Enugu. SagePubication Nigria Ltd

Gyamfi, C.C. 2019. Violence forces O gun APC Presidential Rally to abrupt end. Guard ian Nenspaper. 
Human Rights Watch Report 2011. Ni- Norman, A. S. 2010. Assessment of Elecgeria Post- Election Violence killed 800

Igini, M. 2013. Election Security in Theory and Practice: Perspective of a Resident Electoral Commissioner. Lagos. Fredrich Ebert Stiftung tions Stakeholders in Elections Management. Edurational Research 1(9): 319- 326.

Nwolise, O.B.C. 2007. Electoral Violence and Nigeria's 2007 Elections. Jaumal of AficanEletions6(2)

International Crisis Group 2018. Averting Violence and Nigeria's 2019 E lections. www.crisisgroup.org

Onyema, H.C. 2019. Buhari's order on Ballot- box snatchers: Portents for our Military. TheNigrianVaice www.thenigerianvoice.com

Israel-Ayide, E. 2019. President Buhari's ballot box snatching order should be condemned by all Nigerians. www.pulse.org.

Olasupo, B. 2003. Electoral Violence in Nigeria: Issues and Perspectives. Lagos. Frankad Publishers

Iyare, T. 2018. CLEEN Foundation, SERAP deplore over policing, vote- buying. Nigeria Democratic Report. (Intemational PressCenter).

Joseph, C.E. 2011. Credible Elections and Democratic Consolidation in Nigeria: The moral imperatives. Jaumal of Emerging Trends in Edurational ResearchandPdicy Studies 2(4)

Kayode-Adedeji, D. 2019. O gun APC, APM supporters in bloody clash. Premium Times

Keane, J. 2004. Violence and Democracy. Cambridge. Cambridge University Press

Olatunji, K. 2018. CAN seeks cancellation of Ekiti, O sun Guber Elections. Guardian Nenspaper.

Olurode, L. 2013. Election Security in Nigeria: Matters Arising. Lagos. Fredrich Ebert Stiftung.

Olurode, L., Hammanga, M.K. 2013. D eployment of Security Personnel in Elections: Challenges and Lessons from the field. Lagos. Fredrich Ebert Stiftung

Oni, S., Chidozie, F., Agbude, G. 2013. Electoral Politics in the Fourth Republic of Nigeria's D emocratic Governance. Deudquing Cantry Studies 3(12)

Kimenyi, M., Mbaku, J. 2011. Elections and Violence in Nigeria: The Question of Citizenship in Sub Saharan Africa. Brookings. www.brookings.edu

Otaiku, A. 2018. Military Role in the Nigerian Constitution: An expose of Law and Security impact on D evelopment. Intemational Jaimal of SaientificRearchPubications 8(11)

Mediayanose, 0. E. 2018. The role of Security in Credible Elections and sustenance of D emocracy in Nigeria. Jaumal of Public Administration, Finamce and Law 13(1): 134-141.

Otwin, M. 1985. Policing Nigeria: Control and Anatomy in Exercise of Coercion. Africa Studies Review28

Pomper, G. 1967. The Concept of Elec- 
THE ROLE OF THE NSCDC IN THE 2019 ELECTIO NS...

tions in Political Theory. Reviewof Pditics29 mocracy: Representation and Accountability. (4) Oxford. Oxford University Press

Rosseau, J. 1950. The Social Contract and Ume, O., Ugwu, C., Onu, D. 2016. ImpliDiscourses. New York. Everyman's Library. cations of Militarizing Elections in Nigeria: Ekiti and Osun States. Jaumal of Seeunityand

Sakhawat, H. 2012. Electoral reform in Gldbal Pditics 1(1)

Bangladesh, 1972-2008. D haka: Palok Pub-

lishers.

Thomassen, J. 2014. Elections and De-

(Manuscript reeiveet: 9thA pril, 2019; accepteet 22ndJanuary, 2020 ) 